\title{
Coffee Leaves: An Upcoming Novel Food?\#
}

Authors

Andrea Montis ${ }^{1,2}$, Florence Souard ${ }^{3,4}$, Cédric Delporte ${ }^{1,2}$, Piet Stoffelen ${ }^{5}$, Caroline Stévigny ${ }^{1 *}$, Pierre Van Antwerpen ${ }^{1,2 *}$

Affiliations

1 RD3 Department-Unit of Pharmacognosy, Bioanalysis and Drug Discovery, Faculty of Pharmacy, Université libre de Bruxelles, Brussels, Belgium

2 APFP Analytical platform of the faculty of pharmacy, Faculty of Pharmacy, Université libre de Bruxelles, Brussels, Belgium

3 Département de Pharmacochimie Moléculaire, UMR 5063 CNRS, Université Grenoble Alpes, Saint-Martin d'Hères, France

4 DPP Department - Unit of Pharmacology, Pharmacotherapy and Pharmaceutical care, Faculty of Pharmacy, Université libre de Bruxelles, Brussels, Belgium

5 Meise Botanic Garden, Domein van Bouchout, Meise, Belgium

Key words Coffea, coffee leaves, Rubiaceae, biosynthesis, metabolome, food supplement

received

December 11, 2020

accepted after revision

June 14, 2021

published online

September 24, 2021

\section{Bibliography}

Planta Med 2021; 87: 949-963

DOI 10.1055/a-1533-0021

ISSN 0032-0943

(C) 2021. Thieme. All rights reserved.

Georg Thieme Verlag KG, Rüdigerstraße 14,

70469 Stuttgart, Germany

\section{Correspondence}

Andrea Montis

Ph.D. student/researcher

RD3 Department-Unit of Pharmacognosy,

Bioanalysis and Drug Discovery, Faculty of Pharmacy,

Université libre de Bruxelles

Campus Plaine, CP 205/09, 1050 Brussels, Belgium

Phone: + $32(0) 26505279$

andrea.montis@ulb.be

\section{ABSTRACT}

Unlike those of coffee beans, the healthy properties of coffee leaves have been overlooked for a long time, even if they are consumed as a beverage by local communities of several African countries. Due to the presence of xanthines, diterpenes, xanthones, and several other polyphenol derivatives as main secondary metabolites, coffee leaves might be useful to prevent many daily disorders. At the same time, as for all bioactive molecules, careless use of coffee leaf infusions may be unsafe due to their adverse effects, such as the excessive stimulant effects on the central nervous system or their interactions with other concomitantly administered drugs. Moreover, the presence of some toxic diterpene derivatives requires careful analytical controls on manufactured products made with coffee leaves. Accordingly, knowledge about the properties of coffee leaves needs to be increased to know if they might be considered a good source for producing new supplements. The purpose of the present review is to highlight the biosynthesis, metabolism, and distribution of the 4 main classes of secondary metabolites present in coffee leaves, their main pharmacological and toxicological aspects, and their main roles in planta. Differences in coffee leaf chemical composition depending on the coffee species will also be carefully considered.

\section{Introduction}

Coffee seeds are used all over the world to make the known coffee beverage. The 2 main exported coffee species are Coffea arabica $\mathrm{L}$. $(A R A)$ and Coffea canephora Pierre ex A. Froehner (Rubiaceae, $C A N$ ), which correspond respectively to $56 \%$ and $44 \%$ of the

world's coffee production [1,2]. The share of CAN coffee, also named Robusta coffee, is increasing steadily. ARA is an allopolyploid species $(2 \mathrm{n}=44)$, mostly cultivated across the tropics and subtropics. Wild ARA populations can be found in the southwest of Ethiopia, in northern Kenya, and the eastern part of South Sudan. It is interesting to note that the second main exported cof-

* Equal contribution of these authors.

\# Dedicated to Professor Arnold Vlietinck on the occasion of his 80th birthday. 


$\begin{array}{ll}\text { ABBREVIATIONS } \\ \text { ARA } & \text { C. } \text { arabica } \\ \text { Atr } & \text { atractyloside } \\ \text { CAN } & \text { C. canephora } \\ \text { CGAs } & \text { chlorogenic acids } \\ \text { CPK } & \text { creatine phosphokinase } \\ \text { ERK } & \text { extracellular signal-regulated kinase } \\ \text { HFD } & \text { high-fat diet } \\ \text { IRAK } & \text { interleukin-1 receptor-associated kinase } \\ \text { LDH } & \text { lactate dehydrogenase } \\ \text { MAPK } & \text { mitogen-activated protein kinase } \\ \text { MPTP } & \text { 1-methyl-4-phenyl-1,2,3,6-tetrahydropyridine } \\ \text { mTORK2 } & \text { mTOR complex 2 } \\ \text { NF-kB } & \text { nuclear factor kB } \\ \text { PKC } & \text { protein kinase C } \\ \text { SAM } & \text { S-adenosylmethionine } \\ \text { TGF- } \beta 1 & \text { transforming growth factor beta 1 } \\ \text { TNBS } & \text { 2,3,4-trinitrobenzene sulfonic acid }\end{array}$

fee species, CAN, is genetically closely linked to ARA. Particularly, phylogenetic studies confirmed that CAN and C. eugenioides can be considered the $A R A$ 's progenitor species, each providing half of ARA's genome. It has been assumed that these species hybridized between 1.08 million and 543 thousand years ago and that the emergence of ARA could be related to the environmental changes in East Africa during glacial-interglacial cycles in the last 1 million years [3].

Although the chemical composition of coffee beans has been studied for many years, very limited studies have been performed on the coffee leaf properties and their potential use as a healthy food product.

In several countries, including Ethiopia, India, Indonesia, and Jamaica, sun-dried coffee leaves are currently used as a traditional tea substitute [4]. Moreover, coffee leaves are consumed by the communities of some countries for traditional medicinal purposes. For example, in Ethiopia, coffee leaf infusions are used as a laxative drug [5]. In Mexico, their infusions are used to treat fever, and in Nicaragua, their decoctions have been described as a useful herbal remedy for headaches and stomach pains [6]. In 2018, a notification was submitted to the European Food Safety Authority (EFSA) under Article 14 of the Novel Food Regulation (EU) $2015 / 2283$ to place on the market an infusion from coffee leaves as a traditional food. The 2 relevant species are ARA and CAN. After a rigorous analysis of the request, the EFSA "did not raise safety objections to the placing on the market of the requested product". Coffee leaves could be marketed in the EU as a herbal infusion or as an ingredient for other beverages [7]. One of the main peculiarities of coffee leaf infusions is the higher antioxidant potential and the lower caffeine content: 5 times less compared to the traditional tea and 2 times less compared to mate leaves (Ilex paraguariensis, Aquifoliaceae) ( $\vee$ Table 1$)$ [4]. Indeed, due to the high content of CGAs and xanthones, coffee leaves could be used to prevent several diseases caused by the most common inflammatory processes.
Moreover, recent studies have shown a good efficacy of dietary polyphenols in preventing some severe pathologies. For example, they appear to be useful in preventing some forms of cancer [8] and treating diseases affecting the central nervous system [9].

In addition to the high content of polyphenols, coffee leaves are also a rich source of particular diterpenes and alkaloids. Among the main alkaloids, the most abundant one found in coffee leaves is caffeine [31]. This purine alkaloid is produced by the plant responding to stress (such as predation by insects or fungal infections) [32]. Beneficial effects of pure oral caffeine on oxidative stress have been demonstrated; caffeine could also protect from type 2 diabetes mellitus and its complications and other chronic disorders associated with increased oxidative damage in blood and tissues [33].

Regarding diterpene content, cafestol and kahweol are the 2 main diterpenes found in coffee plants and seeds. Both compounds showed good antidiabetic and anticarcinogenic activities. Particularly, they can inhibit tumor cell activity by inducing their apoptosis [34, 35].

These secondary metabolites can be affected considerably by the environment, the field conditions, the growing season and ecosystem, the plant variety, and age. Other parameters, such as the growth stage of the leaf, can also affect the content of metabolites in coffee leaves. The literature describes 3 different developmental stages for coffee leaves that are categorized as (a) buds and young leaves, (b) mature leaves, and (c) aged leaves [10,36, 37]. Young leaves weigh approximately $25 \mathrm{mg}$ (fresh weight) and are approximately $20 \mathrm{~mm}$ long and $7 \mathrm{~mm}$ wide. Mature leaves are fully expanded, weighing approximately $1.2 \mathrm{~g}$, whereas aged leaves are dark green, they often show dark spots on their surface, and their weight is approximately $1.3 \mathrm{~g}$ [36]. However, some authors do not agree with these standard sizes, which can vary according to the crop location, and have assigned a specific value for coffee leaves used in their experiments. For example, Monteiro et al. [10] claimed that an ARA leaf $7 \mathrm{~cm}$ long and $3 \mathrm{~cm}$ wide could be considered a young leaf.

Moreover, they clearly showed that the size of coffee leaves varies according to each coffee species. Other authors prefer to identify the developmental stage of coffee leaves according to their color and texture. Rodrigues Salgado et al. [37] considered that young leaves are light green, smooth, and recently expanded, whereas mature leaves are intense green and less smooth.

Taking into account the healthy benefits of coffee leaf infusions and considering the emphasized consumption of food supplements in developed countries defined by The European Food Safety Authority as "concentrated sources of nutrients, or other substances with a nutritional or physiological effect marketed in 'dose' form and intended to correct nutritional deficiencies, maintain an adequate intake of certain nutrients, or to support specific physiological functions" [38], this review will gather the biochemical aspects of coffee leaf key metabolites, their possible nutritional or physiological uses, and their toxic aspects. Data will be summarized by grouping the main known pharmacological activities according to in vitro, in vivo, and human studies. A brief overview of the available studies on coffee leaf extracts and the biochemical differences depending on coffee species will also be given. 
- Table 1 Content of the main representative secondary metabolites in the green beans, roasted beans, and mature leaves of Coffea arabica (A) and Coffea canephora (C) and of Camellia sinensis (green tea) and Ilex paraguariensis leaves.

\begin{tabular}{|c|c|c|c|c|c|c|c|c|c|}
\hline \multirow[t]{2}{*}{ Metabolite } & \multicolumn{2}{|c|}{ Coffee leaves } & \multicolumn{2}{|c|}{ Green coffee beans } & \multicolumn{2}{|c|}{ Roasted coffee beans } & \multirow{2}{*}{$\begin{array}{l}\text { Tea leaves } \\
\text { Camellia si- } \\
\text { nensis }\end{array}$} & \multirow{2}{*}{$\begin{array}{l}\text { Mate } \\
\text { leaves } \\
\text { Ilex para- } \\
\text { guariensis }\end{array}$} & \multirow[t]{2}{*}{ References } \\
\hline & (A) & (C) & (A) & (C) & (A) & (C) & & & \\
\hline Caffeine & $2.5-6.0$ & $2.8-7.5$ & $7.6-29.0$ & $15.1-33.3$ & $5.3-20.3$ & $10.6-23.4$ & $36.6-38.0$ & $11.6-18.7$ & [10-19] \\
\hline Trigonelline & $<3.0$ & $4.2-6.0$ & $8.8-27.6$ & $7.5-34.2$ & $<2.5$ & $<2.5$ & - & - & $\begin{array}{l}{[10,13,14,} \\
16,18,20- \\
22]\end{array}$ \\
\hline $\begin{array}{l}\text { Theobro- } \\
\text { mine }\end{array}$ & $<0.1$ & $0.1-0.8$ & $<0.1$ & $<0.1$ & $<0.1$ & $<0.1$ & $1.0-1.2$ & $4.5-11.6$ & $\begin{array}{l}{[10,11,13,} \\
18,19]\end{array}$ \\
\hline $\begin{array}{l}\text { Theo- } \\
\text { phylline }\end{array}$ & $<0.1$ & $<0.1$ & $<0.1$ & $<0.1$ & $<0.1$ & $<0.1$ & - & - & [17] \\
\hline $\begin{array}{l}\text { Chlorogenic } \\
\text { acids* }\end{array}$ & $19.2-39.6$ & $19.3-24.5$ & $57.0-80.3$ & $86.2-102.0$ & $<3.0$ & $<1.0$ & $<14.0$ & $28.8-97.6$ & $\begin{array}{l}{[10,12,14,} \\
16,23-27]\end{array}$ \\
\hline Mangiferin & $0.5-9.2$ & ND & ND & ND & ND & ND & - & - & $\begin{array}{l}{[10,12,28,} \\
29]\end{array}$ \\
\hline Cafestol & $<6.0$ & $<0.1$ & $2.7-11.0$ & $1.5-3.7$ & $<5.0$ & $<3.0$ & - & - & {$[18,24,30]$} \\
\hline Kahweol & ND & ND & $1.1-6.7$ & $1.5-3.7$ & $<10.0$ & ND & - & - & {$[18,24,30]$} \\
\hline
\end{tabular}

Concentrations are expressed as $\mathrm{mg} / \mathrm{g}$ of dry matter and consider the variability depending on the country of harvest and the climatic differences. ${ }^{*} \mathrm{CGAs}$ are expressed as $\mathrm{mg}$ of total CGAs/g of dry matter; $\mathrm{ND}$ = not detected; - = no available information

The experimental research has been conducted by consulting the following websites: Pubmed, ScienceDirect, Google Scholar, Scopus, SciFinder. The keywords searched were: I. coffee (coffea) II. caffeine, III. xanthines, IV. CGAs, V. xanthones, VI. diterpenes, VII. biosynthesis, VIII. coffee leaves, IX. in vitro studies, and X. in vivo studies. The bibliographical research was carried out in English, French, and Italian.

\section{Alkaloids}

The main alkaloids found in coffee leaves are caffeine (1,3,7-trimethylxanthine), theobromine (3,7-dimethylxanthine), theophylline (1,3-dimethylxanthine), and trigonelline.

The first 3 metabolites are classified as purine alkaloids, and among them, caffeine is the major alkaloid in coffee plants $(\triangleright$ Table 1). The role of alkaloids in plants has not been clearly defined, but they do not seem to be used as a nitrogen source to increase the nitrogen pool in the plant organs. One of the main roles of these alkaloids might be defensive. Due to the "chemical defense theory", caffeine production is significantly increased if the plant is subjected to stressful conditions such as nonideal climatic conditions [39]. Insect attacks may also cause caffeine increases in plant tissues to prevent some other infections. For example, it has been shown that when plants of the Camellia genus (Theaceae) are attacked by Xyleborus fornicatus, caffeine biosynthesis increases to prevent fungal infections by Monacosporium ambrosium [40]. Theobroma cacao (Sterculiaceae) plants may inhibit fungal infections by Crinipellis perniciosa by also producing more caffeine. The caffeine content in infected tissues is $7-8$ times higher than the content in healthy tissues, but no information concerning a potential increase of theobromine has been reported [32].

\section{Alkaloids: metabolism and turnover in coffee leaves}

The main caffeine biosynthetic pathway is a reaction including 4 steps: 3 methylations and a hydrolysis reaction. The first step of this pathway is the methylation of the xanthosine by a SAM-dependent $\mathrm{N}$-methyltransferase. The product formed is 7-methylxanthosine. This compound is a substrate of an $\mathrm{N}$-methylnucleosidase that can remove the ribose of the molecule by catalyzing the hydrolysis reaction.

The 2 last steps include 2 methylations, carried out by the theobromine synthase and caffeine synthase. While theobromine synthase may only catalyze the synthesis of the theobromine from 7-methylxanthine, caffeine synthase can use paraxanthine, theobromine, and 7-methylxanthine as a substrate to synthesize caffeine. Xanthosine, the initial substrate for purine alkaloid synthesis, is formed through 4 different pathways: (i) de novo purine biosynthesis, (ii) degradation pathways of adenine nucleotides (AMP route), (iii) guanine nucleotides (GMP route), and (iv) the SAM cycle (SAM route) $[40,41]$.

In coffee plants, biosynthetic activity has been described in both leaves and fruits. The main biosynthetic activity has been found in young leaves of $A R A$, especially in the upper leaves. In the young expanding leaves of ARA plants, theobromine has also been detected but in lower concentrations than caffeine $(\triangleright$ Table 1) [42]. Caffeine is present in cotyledons and leaves in ARA seedlings, but it was not found in the older part of shoots and roots [43]. 
Caffeine accumulates in mature leaves before it is catabolized into theophylline $[44,45]$. Studies on leaf and bud extracts of $A R A$ analyzed by LC-UV showed that caffeine content is greater in young leaves and lower in mature and aged leaves. Results also showed that in mature and aged leaves, the levels of theobromine were significantly reduced. Theophylline was not detected in the leaf extracts [36].

Trigonelline represents the second most abundant alkaloid in coffee leaves. This compound could be considered a reserve compound for nicotinamide adenine dinucleotide (NAD) biosynthesis, but this function is limited to the very early stages of germination of some specific tissues. Some other physiological functions of trigonelline have been proposed in several plants. Trigonelline can be produced in response to oxidative stress; in addition, trigonelline can act as a leaf-closing factor, a cell arrester in $\mathrm{G} 2$, and an inducer of the Nod gene (the Nod gene induction leads to nodule formation, a process facilitating a symbiotic relationship between organisms) [43].

Trigonelline is synthesized from nicotinamide formed during the NAD cycle. The first step of biosynthesis is the deamination of nicotinamide, leading to the formation of nicotinic acid. In coffee leaves, nicotinic acid is mostly converted into trigonelline due to the intervention of a SAM-dependent nicotinate $\mathrm{N}$-methyltransferase. This alkaloid is finally catabolized to nicotinic acid and recycled for NAD synthesis. In tea leaves, though, nicotinic acid is completely converted into nicotinic acid glucoside [46].

\section{Alkaloids: differences between coffee species}

Few studies focused on the content of secondary metabolites in coffee leaves. Monteiro et al. [10] provided some information about the main differences between coffee species. It has been found that ARA had the highest content of caffeine in the leaves. Particularly, caffeine was detected in the leaves of ARA and CAN with concentrations about $15 \mathrm{mg} / \mathrm{g}$ and $12 \mathrm{mg} / \mathrm{g}$ respectively in young leaves, and $6 \mathrm{mg} / \mathrm{g}$ and $5 \mathrm{mg} / \mathrm{g}$ respectively in mature leaves ( $\bullet$ Table 1 ). Results are expressed as $\mathrm{mg} / \mathrm{g}$ of dry matter, and the data have been based on LC-UV analysis. Caffeine has not been found in the leaves of $C$. eugenioides and $C$. racemosa. This study aimed also to highlight the concentration of theobromine and trigonelline in the leaves of these same 4 coffee species. In ARA leaves, the concentration of theobromine was $0.8 \mathrm{mg} / \mathrm{g}$ in the young leaves and $0.04 \mathrm{mg} / \mathrm{g}$ in the mature leaves. In CAN the concentration of theobromine was within the range of $0.1-4 \mathrm{mg} /$ $\mathrm{g}$ in the young leaves and $0.05-0.8 \mathrm{mg} / \mathrm{g}$ in the mature leaves. Theobromine was also found in 1 of 2 C. racemosa genotypes analyzed.

Trigonelline content was higher in the young and mature leaves of C.eugenioides and C. racemosa, approximately $12 \mathrm{mg} / \mathrm{g}$ and $9 \mathrm{mg} / \mathrm{g}$ in $C$. eugenioides leaves and $11 \mathrm{mg} / \mathrm{g}$ and $10 \mathrm{mg} / \mathrm{g}$ in C. racemosa leaves, respectively. In $A R A$ and CAN leaves, trigonelline content was about $12 \mathrm{mg} / \mathrm{g}$ and $3 \mathrm{mg} / \mathrm{g}$ in young and mature leaves of $A R A$ and $6 \mathrm{mg} / \mathrm{g}$ and $5 \mathrm{mg} / \mathrm{g}$ in young and mature leaves of CAN, respectively.

Another study, which focused on ARA, showed that trigonelline content in young and mature leaves of this species is around 4$7 \mathrm{mg} / \mathrm{g}[20]$.

\section{Alkaloids: pharmacology and toxicity}

The beneficial effects of coffee purine alkaloids have been largely demonstrated. In vitro and in vivo studies have been carried out to confirm the efficacy of caffeine in the prevention of some central nervous system diseases. Even if caffeine showed good efficacy, the beneficial effects could be observed only at doses much higher than those ingested with coffee leaf tea.

In vitro studies were performed to demonstrate how caffeine could be considered a regulator of $\mathrm{Ca}^{2+}$ levels in the cell due to its activity on ryanodine receptors and the inhibition of phosphodiesterases. Caffeine is a ryanodine receptor agonist. By activating ryanodine on the sarcoplasmic reticulum, caffeine at mM concentration can increase the amount of intracellular calcium $[47,48]$. Since the metabolic pathways involving the modulation of phosphodiesterase and activation of ryanodine receptors can play a role in some neurodegenerative diseases, caffeine could be used to limit the $\mathrm{Ca}^{2+}$ level dysregulation. However, it seems to be difficult to obtain satisfactory effects by administrating a nontoxic dose of caffeine.

It has also been shown how caffeine, as well as theobromine, might prevent the membrane damages caused by the lipid peroxidation induced by some reactive oxygen species (ROS) like hydroxyl radical $\left({ }^{-} \mathrm{OH}\right)$, peroxyl radical $\left(\mathrm{ROO}^{-}\right)$, and singlet oxygen $\left({ }^{1} \mathrm{O}_{2}\right)$ [49]. In a study carried out by Devasagayam et al. [50], the antioxidant activity of caffeine was compared to that of ascorbic acid, and results obtained by using millimolar doses of caffeine showed that the percent of inhibition of lipid peroxidation induced by ROS in rat liver microsomes was $60.5 \%$ while ascorbic acid exerted only a $21.5 \%$ inhibition. Consequently, it could be concluded that the antioxidant ability of caffeine was significantly higher than ascorbic acid for lipid peroxidation.

An in vitro study has also been performed by Dulloo et al. [51] to investigate the synergistic effect of caffeine and polyphenols (especially catechin derivatives) of green tea extract on thermogenesis stimulation. This effect can be due to the inhibition of noradrenaline degradation exerted by polyphenols and the inhibition of transcellular phosphodiesterases exerted by caffeine. An experiment was carried out to test the effect of these metabolites on the respiration rate of interscapular brown adipose tissue from rats. It was observed that a combination of caffeine $(100 \mu \mathrm{M})$ and catechins $(200 \mu \mathrm{M})$ could significantly increase the respiration rate (2 times more if compared to basal values). In contrast, caffeine and polyphenols alone did not exert a significant effect.

Some in vivo studies allowed highlighting the beneficial effects of caffeine on central nervous system disorders. Protective effects in Parkinson's disease have been studied, and it was concluded that the neuroprotective effects of caffeine in the substantia nigra might be due to competitive caffeine inhibition with adenosine. Caffeine at $300 \mathrm{mg}$ can affect all adenosine receptors, but $\mathrm{A}_{1}$ and $A_{2 A}$ receptors are more susceptive [52]. By inhibiting the activity of $A_{2 A}$ receptors $\left(A_{2 A} R\right)$, caffeine decreases the activation of adenylyl cyclase. Consequently, protein kinase $A$ is less activated, and intracellular calcium levels are decreased, leading to decreased glutamate release from the cells. Thus, caffeine can reduce neuroinflammation by attenuating excitotoxicity. A study carried out on mice showed that in animals treated with $10 \mathrm{mg} /$ $\mathrm{kg}$ of caffeine 10 min before MPTP administration, the residual 
level of dopamine in mice was $40 \%$ of the control (mice treated with saline). Caffeine at $20 \mathrm{mg} / \mathrm{kg}$ could almost fully inhibit the dopamine depletion caused by MPTP, a substance that strongly enhances oxidative stress and upregulates Bax expression and apoptosis of substantia nigra dopaminergic neurons. The effects of caffeine on $A_{2 A} R$ were also compared to those of some synthetic antagonists such us SCH 58261, 3,7-dimethyl-1-propargylxanthine (DMPX), and istradefylline (KW-6002), and it has been shown that in both cases, $A_{2 A} R$ antagonism could significantly reduce striatal dopamine depletion $[52,53]$. It remains to be seen whether a coffee leaf extract containing a smaller dose of chronically administered caffeine could be useful to prevent Parkinson's disease in which an MPTP treatment does not strongly provoke neurological toxicity.

Furthermore, caffeine also showed good efficacy in an Alzheimer's disease mouse model. Indeed, caffeine might reduce the extracellular depositions of diffuse and neuritic plaques composed of the amyloid- $\beta$ peptide. Particularly, the treatment of mice with an average daily dose of $1.5 \mathrm{mg}$ of caffeine for 6 weeks resulted in a reduction of presenilin 1 and $\beta$-secretase, indicating lower hippocampal $\beta$-amyloid levels [54].

Human studies have been carried out to show how caffeine can enhance the effects of some drugs. For example, caffeine can enhance the analgesic effect of acetaminophen. Particularly, a study was designed to compare the analgesic effect of acetaminophen and caffeine alone to a combination of acetaminophen and caffeine in response to tonic and phasic pain stimulation. In this 4-way crossover, double-blind, placebo-controlled study, 24 subjects were treated orally with $1000 \mathrm{mg}$ acetaminophen, $130 \mathrm{mg}$ caffeine, and a combination of both. Results showed analgesic effects of acetaminophen and acetaminophen plus caffeine but not caffeine alone. Moreover, the best results were obtained with the association of acetaminophen and caffeine. In addition, the combination also demonstrated that caffeine accelerated acetaminophen absorption, indicated by a more quickly reached maximum level [55].

Caffeine could also be useful against diabetes. However, Dewar and Heuberger [56] reviewed the effect of caffeine intake on insulin sensitivity and glycemic control by concluding that there are still controversies on the potential utility of this metabolite in the treatment of diabetes. In a double-blinded, randomized, placebocontrolled study, the administration of $250 \mathrm{mg}$ of caffeine or placebo in individuals with a type 1 diabetes diagnosis (T1DM) resulted in significantly decreased episodes of hypoglycemia overnight for the group treated with caffeine. In another randomized, double-blind study, Richardson et al. [57] administrated $5 \mathrm{mg} / \mathrm{kg}$ of caffeine or a placebo to 12 men. Blood glucose and insulin levels were monitored. They showed that subjects who consumed caffeine had higher levels of insulin. However, even if the insulin was increased, the same individuals showed high blood glucose levels, indicating a decrease in insulin sensitivity [58]. In contrast with this last study, Krebs et al. [59] found that glucose levels were only slightly increased after caffeine intake and that no differences in insulin sensitivity could be detected.

However, overconsumption of caffeine may cause some adverse effects, which involve overstimulation of the sympathetic nervous system. Symptoms are anxiety, palpitations, insomnia, hypertension, and muscle spasms [60]. One of the main daily negative consequences caused by the adverse effects of caffeine is insomnia. Drake et al. [61] compared the disruptive sleep effects of caffeine administered in a dose of $400 \mathrm{mg}$ to a group of volunteers at 0,3 , and 6 hours before habitual bedtime. The study results suggested that $400 \mathrm{mg}$ of caffeine taken 0 to 6 hours before bedtime may significantly disrupt sleep compared with the placebo group's sleep quality. Even at 6 hours before bedtime, caffeine reduced sleep by more than 1 hour. In another study performed by Bonnet et al. [62], the administration of $400 \mathrm{mg}$ of caffeine 30 minutes before bedtime drastically reduced sleep quality in treated patients. In addition, significant changes in cardiac function were detected with the electrocardiograms of patients treated with caffeine due to an increase in cardiac sympathetic activity. Nevertheless, considering the content of caffeine in coffee leaves ( $\triangleright$ Table 1 ) and the weight of a traditional tea bag $(2 \mathrm{~g})$, there is no need to be worried about these side effects. However, the problem can arise from drinking "espresso coffee", one of the most common coffee beverages, due to its high caffeine content. A recent study found that the content of caffeine, trigonelline, and nicotinic acid could be strongly influenced by the coffee cultivars and espresso machines that are used. It was concluded that the combination of a temperature of $92^{\circ} \mathrm{C}$ and pressure at 7 or 9 bar is the ideal setting for the most efficient extraction of these compounds. The content of caffeine in a $25 \mathrm{~mL}$ cup of espresso coffee made with these extracting conditions is about 117$200 \mathrm{mg}$ [63].

The second most abundant alkaloid in coffee leaves is trigonelline ( $\triangleright$ Table 1 ). Trigonelline is mainly known for its neuroprotective and hypoglycemic effects. It has been shown that trigonelline at a $50 \mathrm{mg} / \mathrm{kg}$ dose for 28 days may progressively decrease the blood glucose level in streptozotocin- and HFD-induced type 2 diabetes rats. Results showed a decrease from $423.8 \mathrm{mg} / \mathrm{dL}$ glucose in the diabetic control group to $125.4 \mathrm{mg} / \mathrm{dL}$ in diabetic rats treated with trigonelline [64]. The same treatment decreased serum insulin level from $53 \mathrm{mU} / \mathrm{L}$ in the diabetic control group to $41 \mathrm{mU} / \mathrm{L}$ in diabetic rats treated with trigonelline. Moreover, trigonelline has positive effects on diabetes complications such as auditory neuropathy. An improvement of the hearing threshold shift, a delayed latency of the auditory evoked potential, and improved sensory fiber loss in mice with auditory neuropathy induced by pyridoxine was observed after chronic administration of $10 \mathrm{mg} / \mathrm{kg}$ trigonelline [65].

Regarding its neuroprotective effects, trigonelline seemed to be also beneficial in Parkinson's disease. Mirzaie et al. [66] proved that a dose of $100 \mathrm{mg} / \mathrm{kg}$ of trigonelline exerts dose-dependent neuroprotective and anti-apoptotic effects in the case of 6-hydroxydopamine toxicity. Particularly, it has been observed that trigonelline prevented the reduction of the number of Nissl-stained neurons of the substantia nigra pars compacta.

To our knowledge, the only toxic effects linked to trigonelline have been observed at doses much higher than the content of trigonelline that could be reasonably ingested with coffee leaves. In rats, the oral and subcutaneous $\mathrm{LD}_{50}$ doses of trigonelline are $5000 \mathrm{mg} / \mathrm{kg}$. It has been shown that Sabra albino mice fed with $50 \mathrm{mg} / \mathrm{kg}$ trigonelline daily for 21 days did not show alterations in the weight of the thyroid, thymus, adrenals, kidney, liver, uter- 
us, or ovaries. Therefore, no data are available on acute exposure or potential reproductive or teratogenic effects [67].

\section{Polyphenols: Acyl-quinic Acids and Xanthones}

Phenolic compounds are one of the major healthy secondary metabolites present in coffee leaves. Due to their antioxidant properties, polyphenols may be useful to prevent several diseases caused by the oxidation of the main biomolecules. Polyphenols could be used to prevent inflammation and cell apoptosis and to prevent the rise of some forms of cancer [68]. Recently, dietary polyphenols were found useful to prevent prostate cancer [8]. The main known polyphenols of coffee leaves include several derivatives of benzoic, caffeic, $p$-coumaric, protocatechuic, sinapic, ferulic, and acyl-quinic acids [31]. Due to the importance of their presence in coffee tissues and their strong health benefits, this review focused principally on the description of the main acyl-quinic acids and xanthones present in the leaves. It is generally recognized that phenolic compounds are useful in response to biotic or abiotic stress. They could be involved in a possible adaptation of the plants to climate change [69], and they might make the plant more resistant to pests or diseases, such as those induced by insect infections $[70,71]$.

\section{Acyl-quinic acids: metabolism and turnover in coffee leaves}

Acyl-quinic acids are a group of plant-derived compounds produced principally through the esterification of hydroxycinnamic and quinic acid. Clifford et al. [72] found that the main acyl-quinic acid biosynthetic pathway uses phenylalanine as the main precursor. The two first steps of this pathway involve deamination of the phenylalanine, leading to the formation of the cinnamic acid, and then hydroxylation of the latter, leading to the formation of $p$ coumaric acid, catalyzed respectively by a phenylalanine ammonia-lyase and a cinnamate $4^{\prime}$-hydroxylase. The next step is the conversion of $p$-coumaric acid into $p$-coumaroyl-CoA catalyzed by a 4-cinnamoyl-CoA ligase. The $p$-coumaroyl-CoA may be a substrate for 2 different enzymes: a quinate hydroxycinnamoyl transferase and a p-coumaroyl-3'-hydroxylase. The first enzyme catalyzes the synthesis of 5-O-p-coumaroylquinic acid, while the second catalyzes the caffeoyl-CoA synthesis. The caffeoyl-CoA may be directly converted into 5-O-caffeoylquinic acid (5-CQA) or in feruloyl-CoA, thanks to a caffeoyl-CoA-3-0-methyltransferase. Feruloyl-CoA will be used to synthesize 5-O-feruloylquinic acid. Finally, 5-O-p-coumaroylquinic acid may be directly converted into 5-O-caffeoylquinic acid and 5-O-caffeoylquinic acid into 5-Oferuloylquinic acid.

For all these compounds, several isomeric forms exist. For example, 3 different isomers can occur for caffeoylquinic acid, namely chlorogenic acid (5-CQA), neochlorogenic acid (3-CQA), and cryptochlorogenic acid (4-CQA). Among these 3 isomers, the major one present in water leaf extracts is 5-CQA [73]. Moreover, several dimeric forms of these compounds are possible: some dicaffeoyl-quinic acids (diCQA), such as 3,4-diCQA, 3,5diCQA, and 4,5-diCQA, have been found in coffee leaves [74,75].
Table 2 Coffee species with the highest caffeine, trigonelline, chlorogenic acids, and mangiferin in mature leaves.

\begin{tabular}{|l|l|l|l|} 
Metabolite & Species & References \\
\hline Caffeine & $\begin{array}{l}\text { C. arabica } \\
2.5-6.0\end{array}$ & $\begin{array}{l}\text { C. canephora } \\
2.8-7.5\end{array}$ & {$[10]$} \\
\hline Trigonelline & $\begin{array}{l}\text { C. eugenioides } \\
7.8-11.2\end{array}$ & $\begin{array}{l}\text { C. racemosa } \\
9.7-9.8\end{array}$ & {$[10,20]$} \\
\hline $\begin{array}{l}\text { Chlorogenic } \\
\text { acids }\end{array}$ & $\begin{array}{l}\text { C. racemosa } \\
21.7-36.6\end{array}$ & $\begin{array}{l}\text { C. eugenioides } \\
29.4-41.1\end{array}$ & {$[10]$} \\
\hline Mangiferin & $\begin{array}{l}\text { C. anthonyi } \\
>100.0\end{array}$ & $\begin{array}{l}\text { C. salvatrix } \\
>150.0\end{array}$ & {$[23]$} \\
\hline
\end{tabular}

Concentrations are expressed as $\mathrm{mg} / \mathrm{g}$ of dry matter. Little information is available about the content of cafestol and kahweol in coffee species leaves other than ARA and CAN.

\section{Acyl-quinic acids: differences between coffee species}

The content of CGAs found in coffee leaves is greater than the CGA content of tea leaves but lower than that of mate leaves ( Table 1). Monteiro et al. [10] reviewed the content of CGAs and their dimers detected by LC-UV in the young and mature leaves of $A R A, C A N, C$. eugenioides, and $C$. racemosa. It has been found globally that CGA concentration was strongly higher in the young leaves of the four species. Considering the young leaves of these 4 coffee species, ARA showed the highest content of total CGAs with $74 \mathrm{mg} / \mathrm{g}$ of dry matter, while for mature leaves, C. racemosa showed the highest content of total CGAs with $62 \mathrm{mg} / \mathrm{g}$ of dry matter ( $\bullet$ Table 2 ).

Campa et al. [23] described the content of acyl-quinic acids detected by LC-mass spectrometry (MS) in the mature leaves of several African coffee species grown in French tropical greenhouses and several coffee species from Madagascar. Among the 15 analyzed species from Africa, the concentration of acyl-quinic acids was found higher in ARA, C. eugenioides, C. anthonyi, C. stenophylla, C. liberica, and CAN. ARA var. Laurina was the species with the highest content of acyl-quinic acids in the leaves $(40 \mathrm{mg} / \mathrm{g}$ of dry matter). Among the 9 analyzed species from Madagascar, C. leroyi, C. ankaranensis, and C. vohemarensis have been found to have the highest content of acyl-quinic acids. Particularly, C. leroyi contained higher levels of acyl-quinic acids in the leaves $(20 \mathrm{mg} / \mathrm{g}$ of dry matter). Another study, conducted by Rodríguez-Gómez et al. [73], focused on the determination by LC-ECD and LC-MS of the 3 main caffeoylquinic acid isomers in the mature leaves of 7 different African coffee species and 1 subspecies grown in the tropical greenhouses of Meise Botanic Garden (Belgium). Results showed that species with the higher content of total CGAs were $C$. liberica, C. liberica var. liberica, and C. anthonyi with an amount of 203, 124 , and $48 \mathrm{mg} / \mathrm{L}$ of total CGAs, respectively, in aqueous extracts made by suspending $15 \mathrm{mg}$ of dried leaf powder into $1.5 \mathrm{~mL}$ of water.

\section{Acyl-quinic acids: pharmacology and toxicity}

CGAs are known as metabolites efficient in preventing some forms of cancer, diabetes, and obesity. If coffee leaves are used as food supplements, a possible application of these products 
could be to prevent obesity. However, more studies on coffee leaf extracts must be performed to determine which extract concentration should be ingested to observe significant effects.

One of the most important health benefits of these compounds is anticancer activity. It is known that a wide variety of tumors are associated with a dysregulation of the MAPK/ERK signaling pathway. Several mechanisms that could justify the anticancer activity of these compounds have been proposed, and one of them includes the inactivation of the MAPK/ERK signaling pathway. One of the 3 MAPK subfamilies includes ERK $[76,77]$. Normally, the RAS protein, one of the main known oncogenes, can lead to the activation of MEK protein kinase, thus phosphorylating and activating ERK. ERK proteins can activate some transcription factors for genes involved in the regulation of cell survival and proliferation. Yan et al. [78] demonstrated that the combination of CGAs (250 $\mu \mathrm{mol} / \mathrm{L})$ and 5-fluorouracil (5-FU $20 \mu \mathrm{mol} / \mathrm{L})$ significantly inhibited ERK protein phosphorylation in in vitro HepG2 and Hep3B cells. Consequently, significant inhibition of hepatocellular carcinoma cell proliferation could be observed through this mechanism.

Another pathway involved in cancer cell proliferation is associated with the mTORC2. Ritcor, an mTORC2 subunit, may be overexpressed in many gliomas. The activation of mTORC2 caused by the overexpression of Ritcor can enhance cancer cell proliferation and their capacity to invade other tissues $[79,80]$. Furthermore, the Ritcor-mTORC2 complex is important for the organization of the actin cytoskeleton structure [81].

Recently, Tan et al. [82] demonstrated that CGA treatment (5, 20 , and $80 \mu \mathrm{M}$ ) might inhibit the migration and invasive ability of cancer cells by decreasing the phosphorylation of Akt, the expression of Ritcor and F-actin, which is involved in cell growth, and the organization of the actin cytoskeleton.

In vivo studies have been performed to highlight the antidiabetic and anti-obesity activity of CGAs [83]. In induced-obese mice fed with HFD supplemented with chlorogenic acid at $0.02 \%$ $(w / w)$, a decrease of the blood glucose concentration in the circulation could be observed. CGAs are known to inhibit the activity of hepatic glucose-6-phosphatase. Consequently, insulin production is decreased. Moreover, by making glucose unavailable to produce energy, the main energy source is obtained from fat reserves [84].

Huang et al. [85] investigated the effect of 5-CQA on lipid metabolism by feeding Sprague-Dawley rats with an HFD. The rats were randomly assigned to (1) a normal control (NC) group, (2) an HFD control group, (3) an HFD with a low-dose CGA (20 mg/ $\mathrm{kg}$ ) group, and (4) an HFD with high-dose CGA (90 mg/kg). CGA was orally administered once per day for 3 months. In the group treated with the higher dose of CGA, hepatic total cholesterol and triacylglycerol levels were significantly lower than the HFD control group. The anti-obesity activity is still to be tested by chronically administering a modest dose of these compounds.

CGAs are also useful in the treatment of hypertension [86]. Recent studies showed that CGAs $(1 \mu \mathrm{M})$ can relax rat vessels by stimulating the activity of the nitric oxide synthase [87].

Only a few papers dealt with the possible toxic effects of CGAs. Chaube and Swinard studied a possible teratogenic effect of CGAs by administrating high doses of these compounds on rats [88]. Particularly, it has been shown that an administration of 5-
$500 \mathrm{mg} / \mathrm{kg}$ of CGA during gestation did not cause fetal lethality. Concerning the possible carcinogenic effect, it has been found that rats fed with CGAs (2\%) for more than 1 year developed papillomas and carcinomas of the digestive, respiratory, and urinary tract [89]. CGAs should also induce DNA strand breaks, especially when the oxygen radicals formation is enhanced by transition metals [90]. A possible immunotoxic effect has been reported by Kimura et al. [91]. The administration of chlorogenic acid and caffeic acid $\left(2.5 \times 10^{-5} \mathrm{M}\right)$ could inhibit histamine release induced by concanavalin A plus phosphatidylserine in in vitro rat mast cells.

\section{Xanthones: Metabolism and Turnover in Coffee Leaves}

Xanthones are a vast family of compounds found in plants, fungi, and lichens [92]. Chemically speaking, xanthones derive from benzoic acid derivatives and malonyl-CoA, and as shown in - Fig. 1, the main precursor is 3-hydroxybenzoic acid. This compound may react with a molecule of $\mathrm{CoA}$, leading to the formation of 3-hydroxybenzoyl CoA. 3-hydroxybenzoyl CoA reacts with 3 molecules of acetate by forming an unstable intermediate that could be defined as a shikimate-acetate intermediate and is used to synthesize a benzophenone. Consequently, it can be concluded that benzophenones represent the main precursors for the xanthone biosynthesis in plants. The 2 different tetrahydroxybenzophenone isomers that might be formed are then subjected to the ring-closure process, leading to 1,3,5-trihydroxyxanthone and 1,3,7-trihydroxyxanthone. Alternatively, benzoic acid is used as a precursor of biosynthesis. Benzoic acid could be converted in benzoyl-CoA, which may react with 3 molecules of malonyl-CoA, leading to the formation of a 2,4,6-trihydroxybenzophenone. Due to the intervention of a benzophenone-3'-hydroxylase, this intermediate can be transformed into a 2,3',4,6-tetrahydroxybenzophenone, which will be converted in 1,3,7-trihydroxyxanthone $[93,94]$.

Xanthones represent a vast class of compounds, often including xanthone glycosides, prenylated xanthones, and xanthonolignoids found in a dimeric or trimeric form in the plants [94, 95]. It is interesting to note that these metabolites are present in the leaves of $A R A$ while they are undetectable in the fruits ( $\triangleright$ Table 1 ). Xanthone biosynthesis has been found more active in the young leaves when compared with the mature leaves, where the content of xanthones decreases progressively. One of the major xanthones found in coffee leaves is mangiferin ( $\bullet$ Fig. 1 ), which has been shown to decrease with aging. In fact, stage 3 and 2 leaves (leaves from the second and first node below the apex) seem to have 3-fold less mangiferin than the youngest leaves [23].

\section{Xanthones: differences between coffee species}

Among plants studied by Campa et al. [23], the African coffee species that showed the higher mangiferin content were $C$. salvatrix, C. anthonyi, C. eugenoides, and C. pseudozanguebariae. ARA leaves showed a low mangiferin content, while this xanthone has not been detected in CAN leaves. None of the 9 Madagascan species studied contained mangiferin ( $\bullet$ Table 2 ). The different repartition of mangiferin in the leaves of the African species may 
<smiles>CC1=CC(=O)CC(=O)C1C(=O)c1cccc(O)c1</smiles>

3-Hydroxybenzoyl-CoA shikimate-acetate intermediate<smiles>[3H]I</smiles><smiles>CC(C)(C)C</smiles>

2,3',4,6-Tetrahydroxybenzophenone<smiles>O=C(c1cccc(O)c1)c1c(O)cc(O)cc1O</smiles>

2,3',4,6-Tetrahydroxybenzophenone

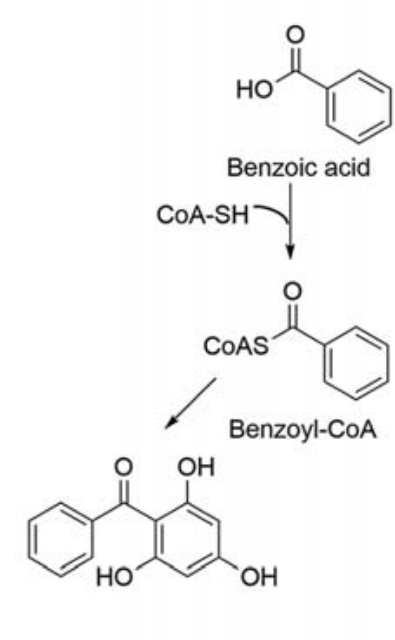

2,4,6-Trihydroxybenzophenone<smiles>O=c1c2cccc(O)c2oc2cc(O)cc(O)c12</smiles>

1,3,5-Trihydroxyxanthone<smiles>O=c1c2cc(O)ccc2oc2cc(O)cc(O)c12</smiles>

1,3,7-Trihydroxyxanthone

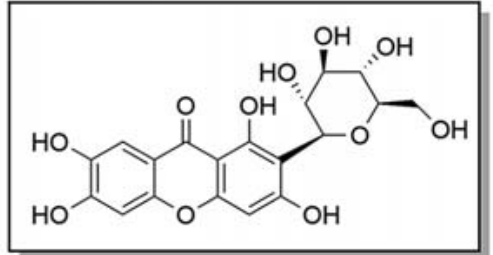

Mangiferin

- Fig. 1 The major biosynthetic pathway of xanthones and chemical structure of mangiferin. Adapted from Schmidt et al. [93]. [rerif]

be because they came from different regions. Current data show that species from East Central Africa and East Africa, such as C. anthonyi, C. salvatrix, and C. pseudozanguebariae, have the highest mangiferin content in the leaves. C. eugenioides leaves also contain high amounts of mangiferin, perhaps because this species and C. anthonyi may be related to ARA's progenitor species. However, C. anthonyi and C. eugenioides do not grow in the same habitats, which means that the genetic closeness between these 2 species should be further investigated [96].

Another study aiming to quantify mangiferin and isomangiferin in ARA leaves from Brazil and Costa Rica by LC-MS showed that the ranges of total mangiferins from Brazil $(0.6-5 \mathrm{mg} / \mathrm{g})$ and Costa Rica $(0.8-4 \mathrm{mg} / \mathrm{g})$ were similar across the samples. However, the content of mangiferin is higher in the leaves of Brazilian plants [28]. Another work highlighted the xanthone composition of young and mature coffee leaves by LC-UV from ARA, CAN, $C$. eugenioides, and $C$. racemosa. It has been confirmed that young coffee leaves had more mangiferin and isomangiferin than mature ones. Furthermore, both xanthone derivatives have not been detected in CAN and C. racemosa leaves. Between C. eugenioides and $A R A, C$. eugenioides leaves showed the highest content of total xanthones (mangiferin and isomangiferin) with a mean of $37 \mathrm{mg} /$ $\mathrm{g}$ of dry matter [10]. A study carried out by De Almeida et al. using LC-MS [29] demonstrated that the contents of flavonoids, CGAs, and xanthones in Brazilian ARA leaves differ according to the re- gion of origin. The highest content, $41 \mathrm{mg} / \mathrm{g}$, was detected in leaves collected in Minas Gerais, whereas a lower content of polyphenols was detected in leaves harvested in São Paulo $(25 \mathrm{mg} / \mathrm{g})$ and Ceará in the Northeast of Brazil $(10 \mathrm{mg} / \mathrm{g})$.

\section{Xanthones: pharmacology and toxicity}

As mentioned above, mangiferin is the main xanthone found in some coffee species, so, consequently, most of the studies described below focus on the pharmacological activity attributed to this molecule. Mangiferin has been described as a molecule useful in preventing inflammatory diseases, such as colitis, and myocardial infarction. Some neuroprotective and antidiabetic effects can also be attributed to mangiferin, but in both cases, the doses necessary to exert a sufficient effect cannot be ingested with coffee leaf tea. Studies performed on the chronic consumption of concentrated extracts will be required.

In vivo studies focusing on its efficacy for myocardial infarction have shown that pretreatment with $10 \mathrm{mg} / 100 \mathrm{~g}$ body weight of mangiferin may decrease the serum levels of marker enzymes such as CPK and LDH and transaminases in isoproterenol myocardial infarcted rats [97]. The benefits of mangiferin could be due to its antioxidant and free radical quenching effects and the increased inhibition of lipid peroxidation $[98,99]$. Xanthones are also useful as a neuroprotective agent. Kavitha et al. [100] have proven the efficacy of xanthones in preventing Parkinson's dis- 

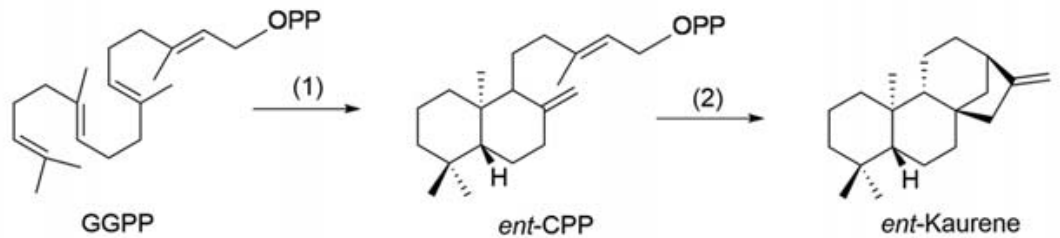

(3)
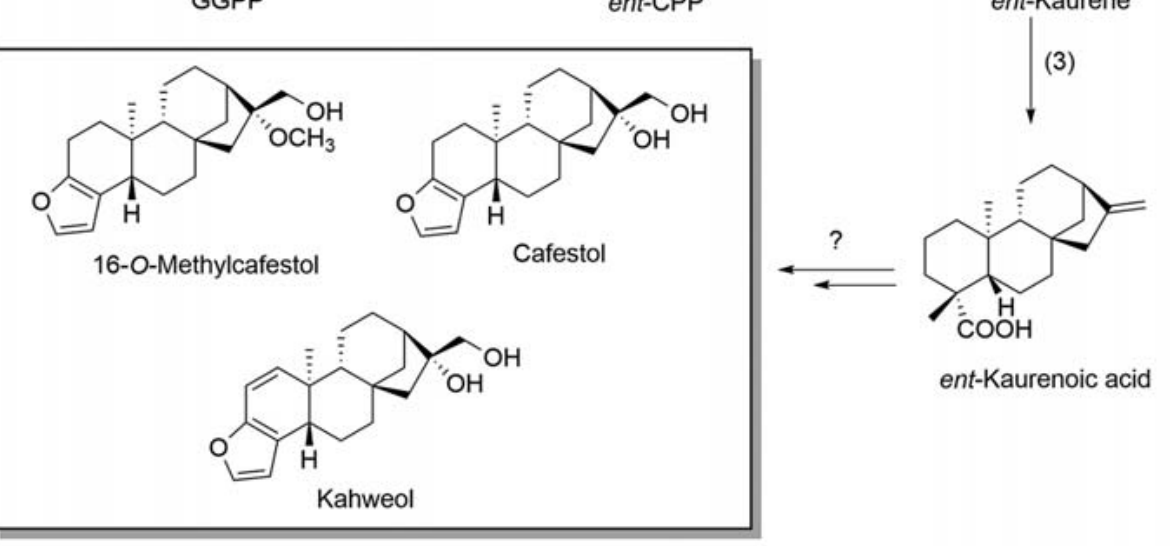

- Fig. 2 The major biosynthetic pathway of diterpenes cafestol and kahweol. (1) copalyl phosphate synthase; (2) ent-kaurene synthase; (3) entkaurene oxidase. Adapted from Pot et al. [110]. [rerif]

ease. The administration of mangiferin for 14 days $(10-40 \mathrm{mg} / \mathrm{kg})$ may prevent dopamine depletion and behavioral deficits in mice treated with MPTP.

In diabetes, mangiferin may significantly decrease plasma glucose levels and simultaneously decrease the risk of developing diabetes complications such as diabetic nephropathy by modulating the MAPK, PKC isoforms, TGF- $\beta 1$ pathways, and NF-KB signaling cascades involved in this pathophysiology $[101,102]$. It has been shown that the administration of $40 \mathrm{mg} / \mathrm{kg}$ bodyweight for 30 days in streptozotocin-induced diabetic rats can decrease glucose levels from $395 \mathrm{mg} / \mathrm{dL}$ to $214 \mathrm{mg} / \mathrm{dL}$. Moreover, the same mangiferin treatment could revert the increase of some nephrotoxicity markers such as plasma creatinine, plasma uric acid, and urinary albumin induced by streptozotocin.

Mangiferin may also prevent other inflammatory disorders such as colitis. Mangiferin $(10 \mu \mathrm{M})$ inhibited the expression of TNF- $\alpha$, IL- $1 \beta$, and IL- 6 by $81 \%, 89 \%$, and $88 \%$, respectively, in lipopolysaccharide (LPS)-treated mice. Furthermore, mangiferin prevented colon shortening, macroscopic score, and colonic-myeloperoxidase-activity in TNBS-induced colitic mice. Mangiferin could also inhibit TNBS-induced IRAK1 phosphorylation and NF-KB activation [103].

Due to their anti-inflammatory activity, xanthones could also play an important role in asthma by reducing eosinophils and prostaglandin D2 in bronchoalveolar lavage fluid by downregulating the levels of cytokines/chemokines and increasing serum Th1related cytokine expression [104].

Though xanthones are considered safe compounds, some toxic effects at high doses have been reported. A subchronic toxicity test that administered 10,50 , and $100 \mathrm{mg} / \mathrm{kg} B W /$ day mangosteen pericarp hydro-extract rich in xanthones to 20 rats for
3 months showed that the kidney of 1 rat had a protruded nucleus in the proximal convoluted tubule. Furthermore, the subjects of the $100 \mathrm{mg} / \mathrm{kg}$ BW/day treated group showed torn glomeruli, but the reason for these disorders has not yet been clarified. However, results could suggest that the safe dosage of the mangosteen pericarp hydro-extract would be less than $100 \mathrm{mg} / \mathrm{kg} \mathrm{BW/}$ day [105]. The content of xanthone derivatives in the aqueous extract is $2-7 \mathrm{mg} / \mathrm{g}$, while the methanol extract contains about $500 \mathrm{mg}$ xanthones $/ \mathrm{g}$ of extract (or $185 \mathrm{mg} / \mathrm{g}$ of dry matter) [106]. The content of mangiferin in the leaves of some coffee species is also about $100 \mathrm{mg} / \mathrm{g}$ of dry matter ( $\triangleright$ Table 2 ).

\section{Diterpenes}

Among diterpene derivatives found in coffee leaves, the ent-kaurane diterpenoids merit particular attention. These compounds were only found in coffee plant tissues, and the major ones are cafestol and kahweol ( $\vee$ Fig. 2) [107]. The plant could use terpenic compounds to respond to biotic or abiotic stress because the compounds improve the plant's defense mechanisms by acting as phytoalexins [108]. It has also been observed that terpenes might be useful to deter herbivores. To our knowledge, no information is available regarding the specific role of the main diterpenes cafestol and kahweol found in coffee plants [109].

\section{Diterpenes: metabolism and turnover in coffee leaves}

Little information concerning the biosynthesis of these compounds is available. Ferreira et al. [111] proposed 1 possible biosynthetic pathway for synthesizing cafestol and kahweol in coffee tissues ( $\bullet$ Fig. 2). According to this pathway, the main precursor should be a unit of geranylgeranyl diphosphate (GGDP). Due to 
the action of a copalyl phosphate synthase, GGDP may be converted into an ent-copalyl disphosphate (CDP). Another enzyme, the ent-kaurene synthase, can thus convert the CDP derivative to ent-kaurene. The last step is oxidation catalyzed by the ent-kaurene oxidase, which leads to the formation of the ent-kaurenoic acid. The conversion of the ent-kaurenoic acid in cafestol, kahweol, and their derivatives has not yet been clarified.

Ent-kaurane diterpenoids have been found in both the fruits and leaves of coffee plants, and their presence in the leaves might be crucial to discriminate several coffee species [112]. No detailed information about the turnover of these diterpenes in coffee leaves is available at the moment.

\section{Diterpenes: differences between coffee species}

Dias et al. conducted a study that explored the content of diterpenes in coffee leaves of CAN and ARA grown in Brazilan and evaluated cafestol and kahweol in coffee tissues by LC-UV/vis [30]. The concentration of cafestol was around $0.5 \mathrm{mg} / \mathrm{g}$ in ARA leaves and around 10 times less in CAN leaves. A negligible amount of kahweol was found only in the leaves of ARA. The class of diterpene derivatives found as discriminant metabolites by Souard et al. [112] might also include some atractyl, diketoatractyligenine, hydroatractylitriol derivatives, etc. Among the 9 species studied by our laboratory, these derivatives have not been detected in the leaves of $A R A, C A N$, and C. anthonyi [112].

\section{Diterpenes: pharmacology and toxicity}

Several healthy effects of coffee consumption are associated with the presence of cafestol and kahweol. Particularly, these compounds could exert a good anticarcinogenic and antidiabetic activity. It is important to clarify that the efficacy in diabetes has only been observed by administering high doses of diterpenes in animals. Moreover, relevant toxic effects have been attributed to some ent-kaurane diterpenes.

The anticarcinogenic activity linked to these compounds might be explained by their capacity to induce apoptotic cell death. Studies on kahweol $(1.0-10 \mu \mathrm{M})$ demonstrated that this compound might activate the mitochondrial caspase-dependent apoptotic pathway, down-regulate the anti-apoptotic proteins, and alter signals linked to Jun $\mathrm{N}$-terminal kinase (JNK) involved in apoptosis [113]. Other studies showed that kahweol at a dose of 20-40 $\mu \mathrm{M}$ might also downregulate the STAT3 signaling pathway and the expression of anti-apoptotic Bcl-2 family proteins in human lung adenocarcinoma A549 cells $[114,115]$. Another proposed mechanism includes the possibility for coffee diterpenes to inhibit angiogenesis involved in cancer growth and metastasis. Moeenfard et al. [116] compared the anti-angiogenic effects of cafestol palmitate and kahweol palmitate in an in vitro angiogenesis model to demonstrate that both compounds at a concentration of $50 \mathrm{mM}$ might inhibit angiogenesis on human microvascular endothelial cells by decreasing the VEGFR2 phosphorylation when compared to control.

Furthermore, anticarcinogenic activity has been explored in vivo by several authors. A study reported that rats fed with cafestol or kahweol palmitate $(60 \mathrm{mg})$ for 3,2 , and 1 day before 7,12 dimethylbenz[a]anthracene administration developed fewer mammary tumors after 4 months when compared with the control group [117].

The antigenotoxic effect of these diterpenes has also been observed. Particularly, cafestol and kahweol may inhibit the covalent binding of aflatoxin B1 metabolites to DNA in microsomal subcellular fractions from livers of treated rats when they are fed with a 52.5: 47.5 mixture of cafestol and kahweol (0-6200 ppm). Significant inhibition was detected at $2300 \mathrm{ppm}$, and maximal reduction of DNA adduct formation was detected with 6200 ppm of dietary cafestol and kahweol [118].

Cafestol can also exert an antidiabetic activity. Mellbye et al. [34] found that this compound can postpone the development of type- 2 diabetes in mice. In this work, 47 male mice were randomly fed with food containing 1.1 (high), 0.4 (low), and 0 (control) $\mathrm{mg}$ of cafestol for 10 weeks. At the end of the experiment, it was found that fasting plasma glucose was about $30 \%$ lower in the cafestol groups than in the control group. Fasting glucagon was $20 \%$ lower, and insulin sensitivity improved by $42 \%$ in the high-cafestol group. Another study aimed to show how kahweol can improve glucose homeostasis in vivo [119]. Particularly, it was observed that upon administration of kahweol $(100 \mathrm{mg} / \mathrm{kg})$ in mice every 2 days, blood glucose clearance was faster than that of control mice. The same study showed that kahweol increases glucose uptake by activating AMPK (AMP-activated protein-kinase) as metformin.

Diterpenes present in the unsaponifiable fraction of coffee can also affect the levels of serum cholesterol. Weusten-Van der Wouw et al. [120] performed a human study with 15 volunteers who have consumed $0.75 \mathrm{~g} /$ day of coffee unsaponifiable fraction for 1 month. A cholesterol increase by $48 \mathrm{mg} / \mathrm{dl}$ was observed when compared to cholesterol levels of placebo. It was concluded that this effect was due to cafestol and kahweol because an administration of the oil deprived of these diterpenes had no effect. Nevertheless, the content of cafestol and kahweol of coffee leaves is very low ( $\triangleright$ Table $\mathbf{1})$. Consequently, ingestion of high amounts of coffee leaf extract would be necessary to observe these adverse effects. More studies would be necessary to conclude that a daily and chronic consumption of low amounts of coffee diterpenes does not represent a risk.

Among the ent-kaurane diterpenes, strong toxic effects have been highlighted for atractyl derivatives. One of the first studies reported fatal renal and hepatic necrosis cases in children after ingestion of herbal remedies containing these molecules [121]. Atr derivatives consist of 2 important chemical groups, an aglycone with a perhydrophenanthrene structure and a glycoside moiety ( $\vee$ Fig. 3). It has been found that the aglycone moiety (atractyligenin) of this class of compounds may have significant toxic effects on mitochondria. More specifically, they are considered a competitive inhibitor of the adenine nucleotide translocase, which is responsible for exchanging ADP and ATP across the mitochondrial inner membrane. The alteration of this pump results in a blockage of oxidative phosphorylation [122,123].

Atr can inhibit gluconeogenesis and fatty acid oxidation, but it can accelerate glycolysis and glycogenolysis. The result is a first acute hyperglycemic phase due to the acceleration of glycogenolysis followed by a marked hypoglycemic phase leading to depression of respiration, tissue hypoxia, convulsion, coma, and in severe 


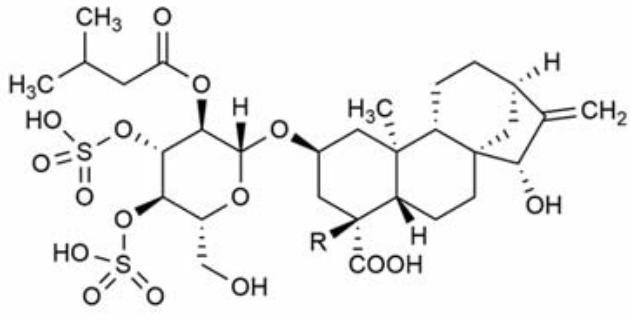

a. $\mathrm{R}=\mathrm{H}$

b. $\mathrm{R}=\mathrm{COOH}$

- Fig. 3 Structures of atractyloside (a) and carboxyatractyloside (b). Adapted from Lang et al. [123]. [rerif]

cases, death. This class of compounds has a $\mathrm{LD}_{50}$ ranging from $15 \mathrm{mg} / \mathrm{kg}$ (dogs, i.v.) to $434 \mathrm{mg} / \mathrm{kg}$ (mouse, i. p.) [124].

Even though these compounds are present in several herbal remedies and coffee plant tissues, high temperatures may reduce their toxicity. Chen et al. [125] showed that Atr could be disrupted by decomposition after heating with water for a long period (decoction). Furthermore, acidification might also accelerate the degradation process. It has been observed that, in some herbal medicines exposed to high temperatures $\left(>98^{\circ} \mathrm{C}\right)$ during decoction and $\mathrm{pH} 2.3$ for $2 \mathrm{~h}$, Atr could be significantly reduced $(40 \%$ of Atr was degraded). Consequently, these compounds can also be degraded during coffee roasting since high temperatures are necessary to perform this process [123]. Other studies proved that oxidation or light irradiation could also remove some of these compounds [126].

\section{Coffee Leaf Extract Activities}

Few studies on coffee leaf extract efficacy have been carried out, and most of them focused only on ARA. Segheto et al. [127] evaluated the inflammatory and antioxidant activity of coffee leaf extract and 5-caffeoylquinic acid in a mouse model. It has been shown that ear edema induced by croton oil was reduced after treatment with ARA leaf methanol extract and 5-caffeoylquinic acid. Particularly, tissue thickness passed from $157 \mu \mathrm{m}$ to $33 \mu \mathrm{m}$ after $0.1 \mathrm{mg}$ extract/ear administration. Moreover, the ear weight was also monitored. An important difference between the control and the treated groups was observed ( $3 \mathrm{mg}$ for the control group vs. $1 \mathrm{mg}$ for the treated group). The administration of $0.1 \mathrm{mg} / \mathrm{ear}$ of 5-caffeylquinic acid reduced the thickness from $154 \mu \mathrm{m}$ to $70 \mu \mathrm{m}$ after $24 \mathrm{~h}$, and the ear weight was $1.7 \mathrm{mg}$. The methanol extract's 5-caffeoylquinic acid and mangiferin content was around $20 \mathrm{mg} / \mathrm{g}$ and $15 \mathrm{mg} / \mathrm{g}$, respectively. Sixty-eight g of leaves were extracted with $1 \mathrm{~L}$ of methanol. Some information about CAN leaf extract is also available. Galam et al. [128] revealed that the aqueous extract exerts an important decrease of rat paw-induced edema. The $120 \mathrm{mg} / \mathrm{kg}$ dose produced the most significant decrease: from $20 \%$ at 20 minutes to $50 \%$ at 120 minutes. The dose that should be administrated to an adult of $70 \mathrm{~kg}$ might be around $8 \mathrm{~g}$ to get a possible benefit. However, the same study was not carried out on humans; consequently, any conclusions are premature.

Chen et al. [20] performed in vitro studies to evaluate the antioxidant and the anti-inflammatory activities of coffee leaves processed by different methods to make different styles of tea. They observed that the Japanese-style green tea-process mature leaves (JGTP-M) resulted in the extract with the highest total polyphenols content. In contrast, black-tea-process mature coffee leaves (BTP-M) was the method providing the extracts with the lowest content of polyphenols. The highest polyphenolic content of the extracts made by JGTP-M was also correlated with their highest anti-inflammatory activity. For example, among the various performed tests, the nitric oxide inhibitory activity was tested. Results showed that the IC-50 for JGPT-M extracts after 0.5 min infusion was 1.7 against $3.0 \mathrm{mg} / \mathrm{mL}$ for BTP-M extracts made with the same infusion duration. Another in vitro study was performed by Chiang et al. [129] to investigate how ARA leaf extract can prevent photoaging by suppressing matrix metalloproteinase (MMPs) expression and MAP kinase pathway. Five, 10 , and $25 \mu \mathrm{g} / \mathrm{mL}$ of coffee leaf extracts could inhibit MMP-1, -3 , and -9 by exerting a dose-dependent inhibition compared to the control group's MMPs levels. In a UVB-induced expression of MAP kinases model performed on human fibroblasts, coffee leaf extract at 5, 10, and $25 \mu \mathrm{g} / \mathrm{mL}$ inhibited JNK phosphorylation in a dose-dependent manner. Moreover, a dose of $25 \mu \mathrm{g} / \mathrm{mL}$ suppressed the ERK activation. It was also shown that a dose of 5 and $10 \mu \mathrm{g} / \mathrm{mL}$ of coffee leaf extract but not $25 \mu \mathrm{g} / \mathrm{mL}$ inhibited the p38 phosphorylation.

\section{Conclusion}

Although coffee beans have been widely studied, this review shows that coffee leaves could also be an important source of the 4 main classes of secondary metabolites found in the Coffea genus. For this reason, coffee leaf extracts might be used as an important feedstock in the nutraceutical industry. Additionally, the levels of some metabolites such as xanthone derivatives were found to be higher in coffee leaves and lower or absent in green and roasted coffee beans, and the content of some purine alkaloids such as caffeine, to which stimulant effects are attributed, was found tendentially lower in coffee leaves compared to Camellia sinensis tea leaves or coffee beans. The in vitro and in vivo activities of metabolites found in coffee leaves were observed at higher concentrations than those present in leaf water extracts. However, less is known about chronic consumption of coffee leaf water extracts and their potential benefits. If beneficial effects are to be highlighted, future formulations of new dietary supplements in tablet or capsule form may be a promising future perspective. However, if concentrated coffee leaf extracts have to be used in daily life as a dietary supplement, special attention should be paid to the presence of some toxic metabolites, and additional studies on the degradation process of these compounds should be carried out. This suggests that it would be preferable, in the first instance, to perform more quality control studies on coffee leaves to ensure the safe consumption of products made with its extracts. 
Therefore, due to the strong biochemical differences between coffee species, more studies would be necessary to employ different coffee species other than ARA and CAN and clarify the potential benefits of their leaf extract.

\section{Contributors' Statement}

Conceptualization: A. Montis. Critical revision of the manuscript: F. Souard, C. Delporte, P. Stoffelen, C. Stévigny, P. Van Antwerpen.

\section{Acknowledgements}

A. Montis gratefully acknowledges the financial support of the Université libre de Bruxelles.

\section{Conflict of Interest}

The authors declare that they have no conflict of interest.

\section{References}

[1] Bedford E. World arabica coffee production 2021. 2020. Accessed January 13, 2021 at: https://www.statista.com/statistics/225400/ world-arabica-coffee-production/

[2] Bedford E. World robusta coffee production 2021. 2020. Accessed January 13, 2021 at: https://www.statista.com/statistics/225402/ world-robusta-coffee-production/

[3] Bawin Y, Ruttink T, Staelens A, Haegeman A, Stoffelen P, Mwanga JCl, Roldán-Ruiz I, Honnay O, Janssens SB. Phylogenomic analysis clarifies the evolutionary origin of Coffea arabica L. J Syst Evol 2020. doi:10.1111/jse. 12694

[4] Ngamsuk S, Huang TC, Hsu JL. Determination of phenolic compounds, procyanidins, and antioxidant activity in processed Coffea arabica $\mathrm{L}$. leaves. Foods Basel Switz 2019; 8: 389

[5] Belayneh A, Bussa NF. Ethnomedicinal plants used to treat human ailments in the prehistoric place of Harla and Dengego valleys, eastern Ethiopia. J Ethnobiol Ethnomedicine 2014; 10: 18. doi:10.1186\% 2F1746-4269-10-18

[6] Ross IA. Medicinal Plants of the World, Volume 3: Chemical Constituents, traditional and modern medicinal Uses. Totowa, NJ: Humana Press; 2005

[7] European Food Safety Authority (EFSA). Technical report on the notification of infusion from coffee leaves (Coffea arabica L. and/or Coffea canephora Pierre ex A. Froehner) as a traditional food from a third country pursuant to Article 14 of Regulation (EU) 2015/2283. EFSA J 2020. doi:10.2903/sp.efsa.2020.EN-1783

[8] Lall RK, Syed DN, Adhami VM, Khan IM, Srivastava SK. Dietary polyphenols in prevention and treatment of prostate cancer. Int I Mol Sci 2015; 16: $3350-3376$

[9] Malar DS, Devi KP. Dietary polyphenols for treatment of Alzheimer's disease-future research and development. Curr Pharm Biotechnol 2014; 15: $330-342$

[10] Monteiro Â, Colomban S, Azinheira HG, Guerra-Guimarães L, Do Céu Silva M, Navarini L, Resmini M. Dietary antioxidants in coffee leaves: impact of botanical origin and maturity on chlorogenic acids and xanthones. Antioxid Basel Switz 2019; 9: 6

[11] Hicks MB, Hsieh YHP, Bell LN. Tea preparation and its influence on methylxanthine concentration. Food Res Int 1996; 29: 325-330

[12] Farah A. Coffee: Production, Quality and Chemistry. London: Royal Society of Chemistry; 2019

[13] Mehari B, Redi-Abshiro M, Chandravanshi BS, Atlabachew M, Combrinck $\mathrm{S}$, McCrindle R. simultaneous determination of alkaloids in green coffee beans from Ethiopia: chemometric evaluation of geographical origin. Food Anal Methods 2016; 9: 1627-1637

[14] Bicho NC, Leitão AE, Ramalho JC, Alvarenga NB, Cebola Lidon F. Identification of chemical clusters discriminators of arabica and Robusta green coffee. Int J Food Prop 2013; 16: 895-904

[15] Silvarolla MB, Mazzafera P, de Lima MMA. Caffeine content of Ethiopian Coffea Arabica beans. Genet Mol Biol 2000; 23: 213-215

[16] Dias RCE, Benassi MDT. Discrimination between Arabica and Robusta coffees using hydrosoluble compounds: is the efficiency of the parameters dependent on the roast degree? Beverages 2015; 1: 127-139

[17] Gramza-Michałowska A. Caffeine in tea Camellia sinensis-content, absorption, benefits and risks of consumption. J Nutr Health Aging 2014; 18: 143-149

[18] Spiller GA. Caffeine. Boca Raton, FL: CRC Press; 2019

[19] Marx F, Janssens MJ], Urfer P, Scherer R. Caffeine and theobromine composition of mate (Ilex paraquariensis) leaves in five plantations of Misiones, Argentina. Plant Foods Hum Nutr 2003; 58: 1-8

[20] Chen XM, Ma Z, Kitts DD. Effects of processing method and age of leaves on phytochemical profiles and bioactivity of coffee leaves. Food Chem 2018; 249: 143-153

[21] Ky CL, Louarn J, Dussert S, Guyot B, Hamon S, Noirot M. Caffeine, trigonelline, chlorogenic acids and sucrose diversity in wild Coffea Arabica L. and C. canephora P. accessions. Food Chem 2001; 75: 223-230

[22] Farah A, Monteiro MC, Calado V, Franca AS, Trugo LC. Correlation between cup quality and chemical attributes of Brazilian coffee. Food Chem 2006: 98: 373-380

[23] Campa C, Mondolot L, Rakotondravao A, Bidel LPR, Gargadennec A, Couturon E, La Fisca P, Rakotomalala J], Jay-Allemand C, Davis AP. A survey of mangiferin and hydroxycinnamic acid ester accumulation in coffee (Coffea) leaves: biological implications and uses. Ann Bot 2012; 110: 595-613

[24] Preedy V. Processing and Impact on Antioxidants in Beverages. Amsterdam: Elsevier; 2014

[25] Vignoli JA, Viegas MC, Bassoli DG, De Toledo Benassi M. Roasting process affects differently the bioactive compounds and the antioxidant activity of Arabica and Robusta coffees. Food Res Int 2014; 61: 279-285

[26] Jeszka-Skowron M, Sentkowska A, Pyrzyńska K, Paz De Peña M. Chlorogenic acids, caffeine content and antioxidant properties of green coffee extracts: influence of green coffee bean preparation. Eur Food Res Technol 2016; 242: 1403-1409

[27] Macheiner L, Schmidt A, Schreiner M, Mayer HK. Green coffee infusion as a source of caffeine and chlorogenic acid. J Food Compos Anal 2019; 84: 103307

[28] Trevisan MTS, de Almeida RF, Soto G, De Melo Virginio Filho E, Ulrich CM, Owen RW. Quantitation by HPLC-UV of mangiferin and isomangiferin in coffee (Coffea Arabica) leaves from Brazil and Costa Rica after solvent extraction and infusion. Food Anal Methods 2016; 9: 2649-2655

[29] De Almeida RF, Trevisan MTS, Thomaziello RA, Breuer A, Klika KD, Ulrich CM, Owen RW. Nutraceutical compounds: echinoids, flavonoids, xanthones and caffeine identified and quantitated in the leaves of Coffea Arabica trees from three regions of Brazil. Food Res Int 2019; 115: 493503

[30] Dias RCE, Campanha FG, Vieira LGE, Ferreira LP, Pot D, Marraccini P, De Toledo Benassi M. Evaluation of kahweol and cafestol in coffee tissues and roasted coffee by a new high-performance liquid chromatography methodology. J Agric Food Chem 2010; 58: 88-93

[31] Chen X. A review on coffee leaves: Phytochemicals, bioactivities and applications. Crit Rev Food Sci Nutr 2019; 59: 1008-1025

[32] Aneja M, Gianfagna T. Induction and accumulation of caffeine in young, actively growing leaves of cocoa (Theobroma cacao L.) by wounding or infection with Crinipellis perniciosa. Physiol Mol Plant Pathol 2001; 59: $13-16$ 
[33] Metro D, Cernaro V, Santoro D, Papa M, Buemi M, Benvenga S, Manasseri L. Beneficial effects of oral pure caffeine on oxidative stress. J Clin Transl Endocrinol 2017; 10: 22-27

[34] Mellbye FB, Jeppesen PB, Shokouh P, Laustsen C, Hermansen K, Gregersen S. Cafestol, a bioactive substance in coffee, has antidiabetic properties in KKAy mice. J Nat Prod 2017; 80: 2353-2359

[35] Choi MJ, Park EJ, Oh JH, Min KJ, Yang ES, Kim YH, Lee TJ, Kim SH, Choi YH, Park JW, Kwon TK. Cafestol, a coffee-specific diterpene, induces apoptosis in renal carcinoma Caki cells through down-regulation of anti-apoptotic proteins and Akt phosphorylation. Chem Biol Interact 2011; 190: 102-108

[36] Ashihara H, Monteiro AM, Gillies FM, Crozier A. biosynthesis of caffeine in leaves of coffee. Plant Physiol 1996; 111: 747-753

[37] Salgado PR, Favarin JL, Leandro RA, De Lima Filho OF. Total phenol concentrations in coffee tree leaves during fruit development. Sci Agric 2008; 65: 354-359

[38] European Food Safety Authority. Food supplements. Accessed April 7, 2021 at: https://www.efsa.europa.eu/en/topics/topic/food-supplements

[39] Frischknecht PM, Ulmer-Dufek J, Baumann TW. Purine alkaloid formation in buds and developing leaflets of Coffea arabica: expression of an optimal defence strategy? Phytochemistry 1986; 25: 613-616

[40] Ashihara H, Sano H, Crozier A. Caffeine and related purine alkaloids: biosynthesis, catabolism, function and genetic engineering. Phytochemistry 2008; 69: 841-856

[41] McCarthy AA, McCarthy JG. The structure of two N-methyltransferases from the caffeine biosynthetic pathway. Plant Physiol 2007; 144: 879889

[42] Fujimori N, Ashihara H. Biosynthesis of theobromine and caffeine in developing leaves of Coffea arabica. Phytochemistry 1994; 36: 1359-1361

[43] Zheng X, Ashihara H. Distribution, biosynthesis and function of purine and pyridine alkaloids in Coffea Arabica seedlings. Plant Sci 2004; 166: 807-813

[44] Ashihara H, Crozier A. Biosynthesis and metabolism of caffeine and related purine alkaloids in plants. Adv Bot Res 1999; 30: 117-205

[45] Dewick MD. Medicinal natural Products: A biosynthetic Approach. Hoboken, NJ: John Wiley \& Sons; 2009

[46] Ashihara H. Metabolism of alkaloids in coffee plants. Braz J Plant Physiol 2006; 18: 1-8

[47] Kong H, Jones PP, Koop A, Zhang L, Duff HJ, Chen SRW. Caffeine induces $\mathrm{Ca} 2+$ release by reducing the threshold for luminal $\mathrm{Ca} 2+$ activation of the ryanodine receptor. Biochem J 2008; 414: 441-452

[48] Boswell-Smith V, Spina D, Page CP. Phosphodiesterase inhibitors. Br J Pharmacol 2006; 147 (Suppl 1): 252-257

[49] Azam S, Hadi N, Khan NU, Hadi SM. Antioxidant and prooxidant properties of caffeine, theobromine and xanthine. Med Sci Monit 2003; 9: 325330

[50] Devasagayam TPA, Kamat JP, Mohan H, Kesavan PC. Caffeine as an antioxidant: inhibition of lipid peroxidation induced by reactive oxygen species. Biochim Biophys Acta 1996; 1282: 63-70

[51] Dulloo AG, Seydoux J, Girardier L, Chantre P, Vandermander ]. Green tea and thermogenesis: interactions between catechin-polyphenols, caffeine and sympathetic activity. Int J Obes 2000; 24: 252-258

[52] Kolahdouzan M, Hamadeh M]. The neuroprotective effects of caffeine in neurodegenerative diseases. CNS Neurosci Ther 2017; 23: 272-290

[53] Chen JF, Xu K, Petzer JP, Staal R, Xu YH, Beilstein M, Sonsalla PK, Castagnoli K, Castagnoli N jr., Schwarzschild MA. Neuroprotection by caffeine and $\mathrm{A}(2 \mathrm{~A})$ adenosine receptor inactivation in a model of Parkinson's disease. J Neurosci Off J Soc Neurosci 2001; 21: RC143

[54] Arendash GW, Schleif W, Rezai-Zadeh K, Jackson EK, Zacharia LC, Cracchiolo JR, Shippy D, Tan J. Caffeine protects Alzheimer's mice against cognitive impairment and reduces brain $\beta$-amyloid production. Neuroscience 2006; 142: 941-952
[55] Renner B, Clarke G, Grattan T, Beisel A, Mueller C, Werner U, Kobal G, Brune K. Caffeine accelerates absorption and enhances the analgesic effect of acetaminophen. J Clin Pharmacol 2007; 47: 715-726

[56] Dewar L, Heuberger R. The effect of acute caffeine intake on insulin sensitivity and glycemic control in people with diabetes. Diabetes Metab Syndr Clin Res Rev 2017; 11: 631-635

[57] Richardson T, Thomas P, Ryder J, Kerr D. Influence of caffeine on frequency of hypoglycemia detected by continuous interstitial glucose monitoring system in patients with long-standing type 1 diabetes. Diabetes Care 2005; 28: 1316-1320

[58] Robinson LE, Savani S, Battram DS, McLaren DH, Sathasivam P, Graham TE. Caffeine ingestion before an oral glucose tolerance test impairs blood glucose management in men with type 2 diabetes. J Nutr 2004; 134: 2528-2533

[59] Krebs JD, Parry-Strong A, Weatherall M, Carroll RW, Downie M. A crossover study of the acute effects of espresso coffee on glucose tolerance and insulin sensitivity in people with type 2 diabetes mellitus. Metabolism 2012; 61: 1231-1237

[60] James J. The influence of user status and anxious disposition on the hypertensive effects of caffeine. Int J Psychophysiol 1990; 10: 171-179

[61] Drake C, Roehrs T, Shambroom J, Roth T. Caffeine effects on sleep taken 0, 3, or 6 hours before going to bed. J Clin Sleep Med 2013; 9: 11951200

[62] Bonnet M, Tancer M, Uhde T, Yeragani VK. Effects of caffeine on heart rate and QT variability during sleep. Depress Anxiety 2005; 22: 150-155

[63] Caprioli G, Cortese M, Maggi F, Minnetti C, Odello L, Sagratini G, Vittori S. Quantification of caffeine, trigonelline and nicotinic acid in espresso coffee: The influence of espresso machines and coffee cultivars. Int J Food Sci Nutr 2014; 65: 465-469

[64] Zhou J, Zhou S, Zeng S. Experimental diabetes treated with trigonelline: Effect on $\beta$ cell and pancreatic oxidative parameters. Fundam Clin Pharmacol 2013; 27: 279-287

[65] Hong BN, Yi TH, Kim SY, Kang TH. High-dosage pyridoxine-induced auditory neuropathy and protection with coffee in mice. Biol Pharm Bull 2009; 32: 597-603

[66] Mirzaie M, Khalili M, Kiasalari Z, Roghani M. Neuroprotective and Antiapoptotic potential of trigonelline in a striatal 6-hydroxydopamine rat model of Parkinson's disease. Neurophysiology 2016; 48: 176-183

[67] Tice R. Trigonelline: review of toxicological literature. 1997. Accessed June 10, 2020 at: https://ntp.niehs.nih.gov/ntp/htdocs/chem_ background/exsumpdf/trigonelline_508.pdf

[68] Carmona-Hernandez JC, Taborda-Ocampo G, Valdez JC, Bolling BW Gonzalez-Correa $\mathrm{CH}$. Polyphenol extracts from three Colombian passifloras (passion fruits) prevent inflammation-induced barrier dysfunction of caco-2 cells. Molecules 2019; 24: 4614

[69] Boudet AM. Evolution and current status of research in phenolic compounds. Phytochemistry 2007; 68: 2722-2735

[70] Eyles A, Bonello P, Ganley R, Mohammed C. Induced resistance to pests and pathogens in trees. New Phytol 2010; 185: 893-908

[71] Orians CM. The effects of hybridization in plants on secondary chemistry: Implications for the ecology and evolution of plant-herbivore interactions. Am J Bot 2000; 87: 1749-1756

[72] Clifford MN, Jaganath IB, Ludwig IA, Crozier A. Chlorogenic acids and the acyl-quinic acids: Discovery, biosynthesis, bioavailability and bioactivity. Nat Prod Rep 2017; 34: 1391-1421

[73] Rodríguez-Gómez R, Vanheuverzwjin J, Souard F, Delporte C, Stevigny C, Stoffelen P, De Braekeleer K, Kauffmann JM. Determination of three main chlorogenic acids in water extracts of coffee leaves by liquid chromatography coupled to an electrochemical detector. Antioxid Basel Switz 2018; 7: 143

[74] Hanson KR. Chlorogenic acid biosynthesis. Chemical synthesis and properties of the mono-o-cinnamoylquinic acids*. Biochemistry 1965; 4: 2719-2731 
[75] Niggeweg R, Michael A], Martin C. Engineering plants with increased levels of the antioxidant chlorogenic acid. Nat Biotechnol 2004; 22: 746754

[76] Lukitasari M, Nugroho DA, Widodo N. Chlorogenic acid: The conceivable chemosensitizer leading to cancer growth suppression. J Evid-Based Integr Med 2018; 23: 1-6

[77] Lu Z, Xu S. ERK1/2 MAP kinases in cell survival and apoptosis. IUBMB Life 2006; 58: 621-631

[78] Yan Y, Li J, Han J, Hou N, Song Y, Dong L. Chlorogenic acid enhances the effects of 5-fluorouracil in human hepatocellular carcinoma cells through the inhibition of extracellular signal-regulated kinases. Anticancer Drugs 2015; 26: 540-546

[79] Masri J, Bernath A, Martin J, Jo OD, Vartanian R, Funk A, Gera J. mTORC2 Activity is elevated in gliomas and promotes growth and cell motility via overexpression of Rictor. Cancer Res 2007; 67: 11712-11720

[80] Chantaravisoot N, Wongkongkathep P, Loo JA, Mischel PS, Tamanoi F. Significance of filamin A in mTORC2 function in glioblastoma. Mol Cancer 2015; 14: 127. doi:10.1186/s12943-015-0396-z

[81] Jacinto E, Loewith R, Schmidt A, Lin S, Ruegg MA, Hall A, Hall MN. Mammalian TOR complex 2 controls the actin cytoskeleton and is rapamycin insensitive. Nat Cell Biol 2004; 6: 1122-1128

[82] Tan S, Dong X, Liu D, Hao S, He F. Anti-tumor activity of chlorogenic acid by regulating the mTORC2 signaling pathway and disrupting F-actin organization. Int J Clin Exp Med 2019; 12: 4818-4828

[83] Cho AS, Jeon SM, Kim MJ, Yeo J, Seo KI, Choi MS, Lee MK. Chlorogenic acid exhibits anti-obesity property and improves lipid metabolism in high-fat diet-induced-obese mice. Food Chem Toxicol 2010; 48: 937943

[84] Naveed M, Hejazi V, Abbas M, Kamboh AA, Khan G], Shumzaid M, Ahmad F, Babazadeh D, FangFang X, Modarresi-Ghazani F, WenHua L, XiaoHui Z. Chlorogenic acid (CGA): A pharmacological review and call for further research. Biomed Pharmacother Biomedecine Pharmacother 2018; 97: 67-74

[85] Huang K, Liang X, Zhong Y, He W, Wang Z. 5-Caffeoylquinic acid decreases diet-induced obesity in rats by modulating PPAR $\alpha$ and $\operatorname{LXR} \alpha$ transcription. J Sci Food Agric 2015; 95: 1903-1910

[86] Suzuki A, Kagawa D, Ochiai R, Tokimitsu I, Saito I. Green coffee bean extract and its metabolites have a hypotensive effect in spontaneously hypertensive rats. Hypertens Res Off J Jpn Soc Hypertens 2002; 25: 99107

[87] Tom ENL, Girard-Thernier C, Demougeot C. The Janus face of chlorogenic acid on vascular reactivity: a study on rat isolated vessels. Phytomedicine Int ] Phytother Phytopharm 2016; 23: 1037-1042

[88] Chaube S, Swinyard CA. Teratological and toxicological studies of alkaloidal and phenolic compounds from Solanum Tuberosum L. Toxicol Appl Pharmacol 1976; 36: 227-237

[89] Hagiwara A, Hirose M, Takahashi S, Ogawa K, Shirai T, Ito N. Forestomach and kidney carcinogenicity of caffeic acid in F344 rats and C57BL/6N x C3H/HeN F1 mice. Cancer Res 1991; 51: 5655-5660

[90] Tice R. Chlorogenic acid and caffeic acid: Review of toxicological literature. 1998. Accessed June 13, 2020 at: https://ntp.niehs.nih.gov/ntp/ htdocs/chem_background/exsumpdf/chlorogenicacid_508.pdf

[91] Yoshiyuki K, Hiromichi O, Takuo O, Tsutomu H, Isao A, Shigeru A. Studies on the activities of tannins and related compounds from medicinal plants and drugs. VI. Inhibitory Effects of caffeoylquinic acids on histamine release from rat peritoneal mast cells. Chem Pharm Bull (Tokyo) 1985; 33: 690-696

[92] Cardona ML, Fernández I, Pedro JR, Serrano A. Xanthones from Hypericum reflexum. Phytochemistry 1990; 29: 3003-3006

[93] Schmidt W, Beerhues L. Alternative pathways of xanthone biosynthesis in cell cultures of Hypericum androsaemum L. FEBS Lett 1997; 420: $143-146$
[94] Wezeman T, Bräse S, Masters KS. Xanthone dimers: a compound family which is both common and privileged. Nat Prod Rep 2015; 32: 6-28

[95] Yang C, Ma L, Wei Z, Han F, Gao J. Advances in isolation and synthesis of xanthone derivatives. 2012; 4: 87-102

[96] Stoffelen P, Noirot M, Couturon E, Bontems S, De Block P, Anthony F. Coffea anthonyi, a new self-compatible Central African coffee species, closely related to an ancestor of Coffea Arabica. Taxon 2009; 58: 133140

[97] Prabhu S, Jainu M, Sabitha KE, Devi CSS. Cardioprotective effect of mangiferin on isoproterenol induced myocardial infarction in rats. Indian J Exp Biol 2006; 44: 209-215

[98] Ghosal S, Rao G, Saravanan V, Misra N, Rana D. A plausible chemical mechanism of the bioactivities of mangiferin. Indian J Chem Sect B 1996; 35: 561-566

[99] Jiang DJ, Tan GS, Ye F, Du YH, Xu KP, Li Y]. Protective effects of xanthones against myocardial ischemia-reperfusion injury in rats. Acta Pharmacol Sin 2003; 24: 175-180

[100] Kavitha M, Nataraj], Essa MM, Memon MA, Manivasagam T. Mangiferin attenuates MPTP induced dopaminergic neurodegeneration and improves motor impairment, redox balance and Bcl-2/Bax expression in experimental Parkinson's disease mice. Chem Biol Interact 2013; 206: 239-247

[101] Han J, Yi J, Liang F, Jiang B, Xiao Y, Gao S, Yang N, Hu H, Xie WF, Chen W. X-3, a mangiferin derivative, stimulates AMP-activated protein kinase and reduces hyperglycemia and obesity in $\mathrm{db} / \mathrm{db}$ mice. Mol Cell Endocrinol 2015; 405: 63-73

[102] Pal PB, Sinha K, Sil PC. Mangiferin attenuates diabetic nephropathy by inhibiting oxidative stress mediated signaling cascade, TNF $\alpha$ related and mitochondrial dependent apoptotic pathways in streptozotocininduced diabetic rats. PloS One 2014; 9: e115364

[103] Jeong JJ, Jang SE, Hyam SR, Han MJ, Kim DH. Mangiferin ameliorates colitis by inhibiting IRAK1 phosphorylation in NF-KB and MAPK pathways. Eur J Pharmacol 2014; 740: 652-661

[104] Imran M, Arshad MS, Butt MS, Kwon JH, Arshad MU, Sultan MT. Mangiferin: a natural miracle bioactive compound against lifestyle related disorders. Lipids Health Dis 2017; 16: 84

[105] Kanokporn C, Patamaporn S, Thanaporn P, Kanjana K. Acute and subchronic oral toxicity of xanthones extracted from the pericarp of Garcinia mangostana Linn.in rat. 2015. Accessed September 11, 2020 at: https://www.asianarchpath.com/view/57

[106] Khaw KY, Chong CW, Murugaiyah V. LC-QTOF-MS analysis of xanthone content in different parts of Garcinia mangostana and its influence on cholinesterase inhibition. J Enzyme Inhib Med Chem 2020; 35: 14331441

[107] Speer K, Kölling-Speer I. The lipid fraction of the coffee bean. Braz J Plant Physiol 2006; 18: 201-216

[108] Singh B, Sharma RA. Plant terpenes: defense responses, phylogenetic analysis, regulation and clinical applications. 3 Biotech 2015; 5: 129151

[109] Singsaas EL. Terpenes and the thermotolerance of photosynthesis. New Phytol 2000; 146: 1-2

[110] Pot D, Ferreira L, Dias RCE, Noel D, Guyot B, Ramos J, Perthuis B, Sandrin P, Benassi MT, Marraccini P, Perreira LFP, Leroy T, Vieira LGE. Genetic and molecular determinism of diterpenes metabolism in Coffea spp. 14-19.09.2008. Accessed June 12, 2020 at: https://www. researchgate.net/publication/311518539_Genetic_and_molecular_ determinism_of_diterpenes_metabolism_in_Coffea_spp/link/ 596f4cf8aca27227101360db/download

[111] Ferreira Lucia P, Dias Rafael C, Noel D, Bernard G, Juliana R, Perthuis B, Sandrin-Garcia P, Benassi MT, Marraccini P, Pereira LF, Leroy T, Vieira LG, Pot D. Determinismo génetico e molecular do metabolismo de diterpenos em Coffea spp. 02-05.06.2009. Accessed June 12, 2020 at: https://agritrop.cirad.fr/551318/ 
[112] Souard F, Delporte C, Stoffelen P, Thévenot EA, Noret N, Dauvergne B, Kauffmann JM, Van Antwerpen P, Stévigny C. Metabolomics fingerprint of coffee species determined by untargeted-profiling study using LC-HRMS. Food Chem 2018; 245: 603-612

[113] Oh JH, Lee JT, Yang ES, Chang JS, Lee DS, Kim SH, Choi YH, Park JW, Kwon TK. The coffee diterpene kahweol induces apoptosis in human leukemia U937 cells through down-regulation of Akt phosphorylation and activation of JNK. Apoptosis Int J Program Cell Death 2009; 14: 1378-1386

[114] Kim HG, Hwang YP, Jeong HG. Kahweol blocks STAT3 phosphorylation and induces apoptosis in human lung adenocarcinoma A549 cells. Toxicol Lett 2009; 187: 28-34

[115] Ekert PG, Silke J, Vaux DL. Caspase inhibitors. Cell Death Differ 1999; 6: 1081-1086

[116] Moeenfard M, Cortez A, Machado V, Costa R, Luís C, Coelho P, Soares R, Alves A, Borges N, Santos A. Anti-angiogenic properties of cafestol and kahweol palmitate diterpene esters. J Cell Biochem 2016; 117: 2748-2756

[117] Wattenberg LW, Lam LK. Protective effects of coffee constituents on carcinogenesis in experimental animals. Banbury Rep 1984; 17: 137145

[118] Cavin C, Holzhäuser D, Constable A, Huggett AC, Schilter B. The coffee-specific diterpenes cafestol and kahweol protect against aflatoxin B1-induced genotoxicity through a dual mechanism. Carcinogenesis 1998; 19: 1369-1375

[119] Baek JH, Kim NJ, Song JK, Chun KH. Kahweol inhibits lipid accumulation and induces Glucose-uptake through activation of AMP-activated protein kinase (AMPK). BMB Rep 2017; 50: 566-571

[120] Weusten-Van der Wouw MP, Katan MB, Viani R, Huggett AC, Liardon R, Lund-Larsen PG, Thelle DS, Ahola I, Aro A, Meyboom S, Beynen AC. Identity of the cholesterol-raising factor from boiled coffee and its effects on liver function enzymes. J Lipid Res 1994; 35: 721-733
[121] Hutchings A, Terblanche SE. Observations on the use of some known and suspected toxic Liliiflorae in Zulu and Xhosa medicine. South Afr Med J Suid-Afr Tydskr Vir Geneeskd 1989; 75: 62-69

[122] Santi R, Luciani S. Atractyloside: Chemistry, Biochemistry and Toxicology. Padova: Piccin Editore; 1978

[123] Lang R, Fromme T, Beusch A, Wahl A, Klingenspor M, Hofmann T. 2-O- $\beta$-D-Glucopyranosyl-carboxyatractyligenin from Coffea L. inhibits adenine nucleotide translocase in isolated mitochondria but is quantitatively degraded during coffee roasting. Phytochemistry 2013; 93: 124-135

[124] Obatomi DK, Bach PH. Biochemistry and Toxicology of the Diterpenoid Glycoside Atractyloside. Food Chem Toxicol 1998; 36: 335-346

[125] Chen LY, Hu A, Chang CJ. The degradation mechanism of toxic atractyloside in herbal medicines by decoction. Molecules 2013; 18: 20182028

[126] Buscemi S, Rosselli S, Bruno M, Vivona N, Piozzi F. Photoinduced functionalization of diterpenes: transformation of the C-20 methyl of atractyligenin into a carbomethoxymethyl or carbamoylmethyl group. J Photochem Photobiol Chem 2003; 155: 145-149

[127] Segheto L, Santos BCS, Werneck AFL, Pinto Vilela FM, Vieira de Sousa $\mathrm{O}$, Pereira Rodarte M. Antioxidant extracts of coffee leaves and its active ingredient 5-caffeoylquinic acid reduce chemically-induced inflammation in mice. Ind Crops Prod 2018; 126: 48-57

[128] Galam NZ, Gambo IM, Rabiu A, Chinelo N, Dami S. Anti-inflammatory effect of aqueous extract of coffee plant leaves (Coffea canephora) in rats. J Nat Sci Res 2013; 3: 191-193

[129] Chiang HM, Lin TJ, Chiu CY, Chang CW, Hsu KC, Fan PC, Wen KC. Coffee arabica extract and its constituents prevent photoaging by suppressing MMPs expression and MAP kinase pathway. Food Chem Toxicol 2011; 49: $309-318$ 